\title{
Pelaksanaan Eksekusi Hadhonah Bagi Pasangan Yang Bercerai Di Pengadilan Agama Curup Tahun 2016
}

\author{
Zainal Arifin \\ Institut Agama Islam Negeri (IAIN) Curup \\ zainal.naik@gmail.com
}

\begin{abstract}
This research aims to give a identification about Hadhanah's problems which were often separated with claims or divorce requests. The phenomenon of child custudy disputes for small regional areas such as in city of Curup is not understood yet by the public. The lack of understanding about it sometimes makes what has been decided by the court is not implemented by the parties concerned. This research was field research with qualitative approach. In assessing the primasy data obtained from the interview, the researcher used interative libraries such as the Alquran and hadith. From the research, it is found that, first the number of hadhanah's case at Curupreligious court class I B in 2016 is one case with the case number 262/Pdt.G/2016/PA.Crp. Second, the exsecution of hadhanah's case at curupreligious courts in class I B in 2016 has never been done because the public understanding of the execution is still lack, the cost of execution is quite expensive and the strength of family principles in solving problems. Last, the consistency of the level of execution of hadhanab's caseinCurup religious courts in class I B in 2016 can not be seen and can not be found. It is because there has never been any parties who have filed an appeal or a request for a cassation against hadhanah's verdict.
\end{abstract}

Keyword: Execution, Implementation, Hadhanah

\begin{abstract}
Abstrak
Tujuan penelitian ini adalah untuk memberikan pencerahan kepada masyarakat mengenai perselisihan hak asuh anak di wilayah kota Curup ini yang belum terlalu dipahami masyarakat. Dari kekurangan pemahaman tersebut terkadang apa yang sudah diputuskan oleh pengadilan tidak dilaksanakan oleh pihak-pihak terkait.Penelitian ini adalah penelitian lapangan atau field research dengan pendekatan kualitatif. Dalam mengkaji data primer yang didapat dari wawancara penulis menggunakan literatur kepustakaan seperti Alquran dan hadits. Dari penelitian yang dilakukan maka penulis mendapatkan hasil penelitian pertama, jumlah perkara
\end{abstract}

Al Istinbath : Jurnal Hukum Islam vol. 3, no. 1, 2018

STAIN Curup-Bengkulu | p-issn: 2548-3374; e-issn: 2548-3382

Available online at : http://journal.staincurup.ac.id/index.php/alistinbath 
hadhonah di Pengadilan Agama Curup kelas 1B tahun 2016 adalah satu perkara yaitu perkara Nomor 262/Pdt.G/2016/PA.Crp. Kedua, Pelaksanaan eksekusi putusan perkara hadhonah di Pengadilan Agama Curup kelas 1B tahun 2016 belum pernah dilakukan dikarenakan pemahaman masyarakat mengenai eksekusi masih kurang, biaya eksekusi yang tergolong mahal dan masih kuatnya asas kekeluargaan dalam masyarakat dalam menyelesaikan masalah. Dan terakhir, konsistensi tingkat pelaksanaan putusan perkara hadhonah di Pengadilan Agama Curup kelas 1B tahun 2016 tidak dapat terlihat dan tidak dapat ditemukan. Hal tersebut disebabkan belum pernah ada pihak-pihak berpekara yang mengajukan banding maupun permohonan kasasi terhadap putusan hadhanah.

Kata kunci: Eksekusi, Pelaksanaan, Hadhanah

\section{Pendahuluan}

Hadhanah sebagai salah satu akibat putusnya perkawinan diatur secara panjang lebar oleh Kompilasi Hukum Islam (KHI). Dan materi yang terkandung didalamnya berasal dari figh menurut Jumhur ulama. Selain mengenai hadhanah dan kewajiban nafkah bagi ayah, pasal 156 KHI juga menegaskan bahwa jika terjadi perselisihan mengenai hadhanah dan nafkah anak maka bisa diselesaikan di Pengadilan Agama. ${ }^{1}$ Pengadilan Agama menyelesaikan perselisihan harus berdasarkan ketentuan pasal 156.

Mengenai perselisihan tentang hadhanah inilah yang menarik bagi penulis untuk diteliti lebih dalam. Penulis ingin melihat seberapa banyak perkara hadhanah yang ada di Pengadilan Agama Curup. Dan bagaimana putusan hadhanah yang ada di Pengadilan Agama Curup lebih dominan jatuh ketangan ibua tau ayah beserta alasannya.

Berdasarkan data yang penulis dapat dari Lembaga Konsultasi dan Bantuan Hukum (LKBH) Alumni Syariah STAIN Curup tahun 2016, banyak sekali perkara cerai gugat maupun cerai talak yang tidak mencantumkan permohonan maupun gugatan mengenai hadhanah. Permasalahan hadhanah sering terpisah dengan gugatan maupun permohonan cerai. Fenomena perselisihan hak asuh anak untuk wilayah daerah kecil seperti kotaCurup ini merupakan hal yang belum terlalu dipahami masyarakat.

Dari kekurangan pemahaman tersebut terkadang apa yang sudah diputuskan oleh pengadilan tidak dilaksanakan oleh pihak-pihak terkait. Contohnya misalkan sebuah perkara hadhanah dimenangkan oleh ibu $\mathrm{A}$, dan bapak B harus memberikan nafkah anaknya setiap bulan Rp 2.000.000,-. Namun tidak dilaksanakan oleh si B. Lantas bagaimana kelanjutan dari eksekusi putusan

${ }^{1}$ SulaikinLubis, et all, Hukum Acara Perdata Peradilan Agama di Indonesia, Jakarta:Kencana Prenada Media Group, 2008, Cet. ke-3., h. 295. 
pengadilan Agama tentang hadhanah dan nafkah anak tersebut. Oleh sebab itu penulis ingin menemukan pelaksanaan eksekusi hadhanah bagi pasangan yang bercerai di Pengadilan Agama Curup.

\section{Pembahasan}

Hadhanah menurut bahasa adalah Al-Janbu berarti erat atau dekat. Sedangkan menurut istilah memelihara anak laki-laki atau perempuan yang masih kecil dan belum dapat mandiri, menjaga kepentingan anak, melindungi dari segala yang dapat membahayakan dirinya, mendidik rohani dan jasmani serta akalnya supaya si anak dapat berkembang dan dapat mengatasi persoalan hidup yang akan dihadapinya ${ }^{2}$ Pengertian ini selaras dengan pendapat yang dikemukakan oleh sayid sabiq bahwa hadhanah adalah melakukan pemeliharaan anak yang masih kecil laki-laki atau perempuan atau yang sudah besar belum mumayyiz tanpa kehendak dari siapapun, menjaga dari sesuatu yang menyakiti dan merusaknya, mendidik jasmani dan rohani agar mampu berdiri sendiri menghadapi hidup dan memikul tanggung jawabnya. ${ }^{3}$

1. Dasar Hukum

Hubungan antara orang tua dengan anak dalam hal ini adalah hubungan wajib tidak bisa putus atau terhalang keadaan sesuatu apapun baik karena perceraian maupun salah satunya meninggal dunia, tidak menyebabkan putusnya kewajiban terhadap anaknya sesuai dengan firman Allah SWT:

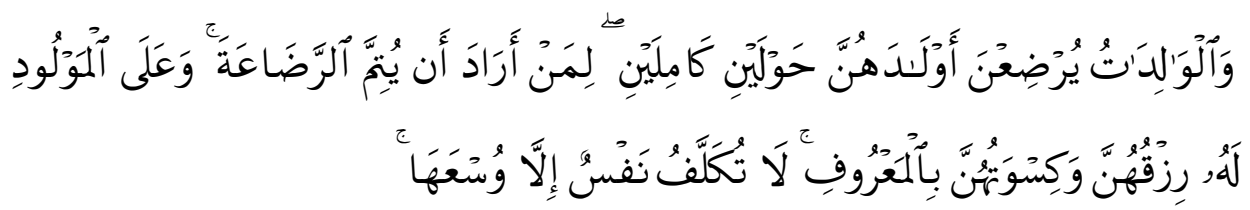

Para ibu bendaklah menyusukan anak-anaknya selama dua tabun penuh, Yaitu bagi yang ingin menyempurnakan penyusuan. dan kewajiban ayah memberi Makan dan pakaian kepada Para ibu dengan cara ma'ruf. seseorang tidak dibebani melainkan menurut kadar kesanggupannya.......(QS. Al Baqarah ; 233) ${ }^{4}$

Ayat tersebut dipahami bahwa seorang ayah berkewajiban untuk memberikan nafkah kepada istri dan anak-anaknya. ${ }^{5}$ Sedangkan dalam pemeliharaan anak yang setelah bercerai antara suami dan istri, rupanya

${ }^{2}$ Hakim Rahmat, Hukum Perkawinan Islam, (Bandung, Pustaka Setia, 2000), h.224.

${ }^{3}$ Sayyid Sabiq, Fiqih Sunnah Jus 8, (Bandung, Al-Ma'ruf, 1984), h.179.

${ }^{4}$ Departemen Agama, Al-Quran dan Terjemahnya.(Bandung: Diponegoro. 2006 ), h. 30.

${ }^{5}$ H. A. Al-Hamdani, Risalah Nikah (Jakarta: Pustaka Amini, 2002), h.,321-322. 
prioritas jatuh pada seorang ibu yang paling berhak untuk mengasuhnya.Hal ini berdasarkan hadis yang diriwayatkan oleh At-tirmidzi:

"Dari ibnu Syuaib dari ayahnya dari kakeknya yakni Abdullab bin Umar dan sesunggubnya seorang wanita berkata: Wahai Rasulullah, sesunggubnya anak saya ini perutku adalah kantongnya, pangkuanku adalah tempat duduknya, dan susuku adalah tempat minumnya, maka setelah mendengar aduan itu, kemudian Nabi Mubammad SAW bersabda:"Engkaulah yang lebih berbak menjaga anak itu selama engkau belum kawin dengan yang lain."

2. Kategori Orang Yang Berhak Melakukan Pemeliharaan Anak

Seseorang anak dari permulaan hidupnya sampai pada umur tertentu memerlukan orang lain untuk membantunya dalam kehidupanya, baik seperti makan minum dan lainnya. Oleh karena itu orang yang menjaganya perlu rasa kasih sayang, kesabaran, serta mempunyai keinginan agar anak itu baik di kemudian hari. Dan yang memiliki syarat-syarat tersebutadalah wanita. Maka menetapkan bahwa wanitalah yang pantas dalam pemeliharaan ini. Sebagaimana di sebutkan dalam hadist, yang berbunyi:

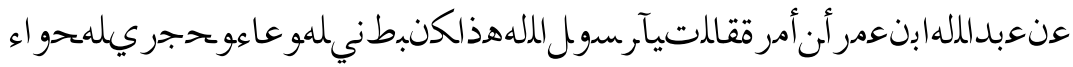

Dari Abdullah Bin Umar babwasanya seorang wanita berkata: ya rasulullah, babwasanya anakeku ini perut kulah yang mengandungnya, asubankulah yang mengawasinya, air susukulah yang diminumnya. Bapaknya hendak mengambilnya dariku. Maka berkatalah rasulullab: engkan lebih berbak atasnya selama engkan belum menikah lagi dengan laki-laki lain.

Jika ibunya telah meninggal ataupuntidak ada maka yang menjadi badhanah ibu dari ibunya anak itu terus keatas.Jika tidak ada lagi yang melakukan hadhanabmaka yang terkahir memiliki wewenang adalah pemerintahnya. Urutan orang-orang yang berhak melakukan dalam badhanah yaitu :

a. Kerabat pihak ibu didahulukan atas kerabat pihak bapak jika tinggkatannya dalam kerabat adalah sama.

b. Kerabat sekandung didahulukan dari kerabat yang bukan sekandung dan kerabat seibu lebih didahulukan atas kerabat bapaknya dan lainnya.

3. Syarat-Syarat Hadbinah Dan Hadhin

Ada beberapa hal yang harus diperhatikan oleh hadbinah dan badbin sebagai syarat yaitu:

${ }^{6}$ Al-Hafizh ibn Hajar Asqalani, Op.cit., h. 359.

${ }^{7}$ Al-Hafizh ibn Hajar Asqalani, Op.cit., h. 377. 
a. Tidak terikat dengan sesuatu pekerjaan yang menyebabkan ia tidak melakukan hadhanah dengan baik, seperti hadhinah terikat dengan pekerjaan yang berjauhan sehingga masa hadhanahnya dihabiskan untuk bekerja.

b. Hendaknya mempunyai kemampuan untuk melakukan hadhanah.

c. Hadbinah hendaklah orang yang tidak membenci si anak jika hadhinah orang yang membenci si anak di khawatirkan akan terjadinya kesengsaraan terhadap si anak dan lainnya. ${ }^{8}$

\section{Pendapat Ulama Tentang Hadhanah}

Para ulama berbeda pendapat tentang hadhanah ini, siapakah yang berhak itu hadhina atau madhun (anak). Sebagian pengikut mazhab hanafi berpendapat bahwa hadhanab itu hak anak, sedangkan menurut Imam Syafi'I, Ahmad, serta sebagian pengikut mazhab Imam Maliki berpendapat bahwa hadhanah itu haknya hadhin. Anak termasuk salah satu anggota keluarga, jadi terpeliharanya dari api neraka hak anak yang wajib dilaksanakan orang tuanya, sebagaimana Firman-Nya:

Hai orang-orang yang beriman, peliharalah dirimu dan keluargamu dari neraka yang bahan bakaranya adalah manusia dan batu.

Oleh karena itu badhin terutama orang tuanya, berhak atas pendidikan dan pemeliharaan anak, karena ia memerlukan ketaqwaan anak itu, sebagaimana hadist Rasulullah :

Rosulullah bersabda, apabila seorang manusia meninggal dunia putuslah amalnya, kecuali tiga perkara: anak sholeh yang selalu mendoakannya, shodakoh jariah serta ilmu yang bermanfaat..$^{10}$

Dari keterangan diatas nyatalah haknya hadhin serta madhun. Tentu saja dalam pelaksanaannyadiperlukan suatu kebijakan sehingga tidak memberatkan diantara kedua belah pihak.

5. Masa Hadhanah

Didalam Alquran serta hadist secara tegas tidaklah terdapat tentang masa hadhanah, hanya saja terdapat isyarat-isyarat yang menerangkan ayat tersebut. Oleh karena itu hanya saja para ulama berijtihad sendiri-sendiri, seperti halnya mazhab Hanafi berpendapat bahwa hadhanah anak laki-laki habis pada waktu dia tidak memerlukan penjagaan serta dapat mengurus h.106.

${ }^{8}$ Abdul Aziz Dahlan, Ensiklopedia Hukum Islam, (Jakarta: Ikhtiar Baru Van Hove, 1999),

9Syaikh al-Allamah Muhammad bin Abdurrahman ad-Dimasyqi, Fikib Empat Mažbab, terj. Abdullah Zaki Alkaf, (Bandung: Hasyimi, 2010), Cet. ke-13, h. 357.

${ }^{10}$ Ibid., hal 357. 
28 Al-Istinbath: Jurnal Hukum Islam, Vol. 3, No. 1, 2018

kepentingan pribadinya, sedangkan wanita habis pada saat haid pertamanya. ${ }^{11}$ Sedangkan pendapat para mazhab Imam Syafi'i, hadhanab itu berkhir ketika sianak telah mummayyiz atau berumur lima ataupun enam tahun, dengan dasar:

Rosulullab bersabda, anak ditetapkan pada bapak dan ibunya sebagaimana belum mumayyir, perempuan ditetapkan pada bapak dan ibunya. ${ }^{12}$

6. Upah Hadhanah

Ibu tidak berhak atas upah badhanah seperti menyusui, selama ia masih menjadi istri dari bapak anak itu, atau masih dalam masa iddahnya. Karena dalam keadaan tersebut ia masih dalam keadaan dinafkahi, firman Allah Swt:

Para ibu hendaklah menyusukan anak-anak selama dua tabun penuh, yaitu bagi yang ingin menyempurnakan penyusuannya, dan kewajiban ayah memberikan nafkah labir batbin kepada ibu dengan cara yang makruf. ${ }^{13}$

Adapun habis masa iddahnya maka berhak atas upah badhanah tersebut Allah Swt. berfirman :

Maka berikanlah kepada mereka nafkahny a sehingga mereka bersalin, kemudian jikea mereka menyusukan anak-anakmu untukmu maka berikanlah kepada mereka upahnya, dan musyawarablah diantara kamu dengan baik, dan jika kamu menemui kesulitan maka perempuan lain boleh menyusukan anak itu untuknya. ${ }^{14}$

Tentang pemeliharaan yang belum mumayyir, sedangkan keduanya bercerai, Kompilasi Hukum Islam menjelaskan: ${ }^{15}$

\section{Pasal 105}

1) Pemeliharaan anak yang belum mumayyiz atau belum berumur 12 tahun maka hak ibunya.

2) Pemeliharaan anak yang sudah mumayyiz diserahkan kepada anaknya untuk memilih diantara bapaknya.

3) Biaya pemeliharaan ditanggung bapaknya.

Pasal 106

${ }^{11}$ Ibid., hal 358.

${ }^{12}$ Achmad Sudarto dkk, Terjemah Shabih Bukhari Jilid VII, (Semarang: CV. AsySyifa, 1993), h. 287.

${ }^{13} \mathrm{Al}-\mathrm{Baqarah}$ ayat 233.

${ }^{14}$ At- Talaq ayat 6.

${ }^{15}$ Ahmad Rofiq, Op.cit., hal 379. 
1) Orang tuanya berkewajiban merawat dan mengembangkan harta anaknya yang belum dewasa atau dibawah pengampuan dan tidak diperbolahkan memindahkan kecuali karena keperluan mendesak.

2) Orang tua bertanggung jawab atas kerugian atasyang ditimbulkan karena kesalahan dan kelalaian dari dari kewajiban tersebut pada ayat (1)

\section{Hak Anak dalam Hukum Islam}

Untuk membandingkan hak dan kewajiban yang ada dalam UU Perlindungan Anak maka di bawah ini penulis jabarkan hak terhadap anak dalam hukum Islam. Dimulai dengan hak antara lain sebagai berikut :

1. Anak berhak untuk hidup, tumbuh dan berkembang. Islam melarang orang tua untuk membunuh anak-anak mereka dengan tujuan apapun. Perlindungan untuk hidup, tumbuh dan berkembang tersebut diberikan Islam sejak masa dalam kandungan. Sebagaimana terdapat dalam Alquran surat al-Isra ayat 31 :

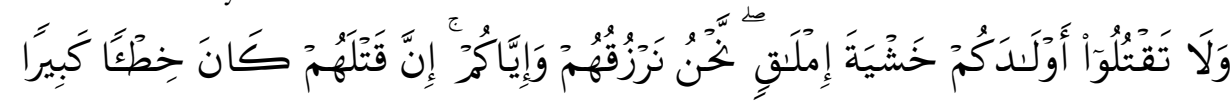

'Dan janganlah kamu membunuh anak-anakmu karena takut kemiskinan. Kami-lah yang akan memberi rezeki kepada mereka dan juga kepadamu. Sesunggubnya membunub mereka adalah suatu dosa yang besar".

2. Hak atas suatu nama, identitas diri, status dan mengetahui orang tuanya.

Anak berhak mendapatkan nama dan identitas diri dalam Islam. Untuk nama anak, Allah swt telah mengisyaratkan dalam Alquran bahwa anak harus diberi nama.

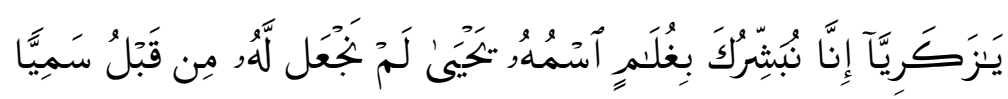

"Hai Zakaria, sesunggubnya Kami memberi kabar gembira kepadamu akan (beroleh) seorang anak yang namanya Yahya, yang sebelumnya Kami belum pernah menciptakan orang yang serupa dengan dia" (QS. Maryam: 7).

3. Hak memelihara, membesarkan dan mengasuh.

Nabi saw memerintahkan kepada orang tua untuk membesarkan dan mengasuh anak. Nabi Muhammad saw pernah menetapkan hak hadanah kepada seorang ibu (janda) selama dia belum melakukan perkawinan lagi dengan orang lain. Rasulullah saw bersabda:

"Engkan lebih berbak terbadapnya selama engkau belum berkawin." (Riwayat Ahmad dan Abu Dawud) 
30 | Al-Istinbath: Jurnal Hukum Islam, Vol. 3, No. 1, 2018

Hak dan tanggung jawab seorang ibu dalam mengasuh dan membesarkan anaknya berlangsung hingga anak mencapai mumayyiz.

4. Hak memperoleh pelayanan kesehatan dan jaminan sosial.

Rasulullah saw menjenguk, mendoakan kesembuhan dan mengobati anak-anak yang sakit. Dari As-Saib bin Yazid berkata : "Bibiku membawaku pergi menemui Rasulullah lalu berkata, Wahai Rasulullah, keponakanku ini sedang sakit. Maka Rasulullab mengusap kepalaku dan mendoakan keberkahan bagiku dan beliau berwudu lalu aku minum dari bekas air wudunya. Setelab itu aku berdiri di belakang punggungnya dan kulibat cap kenabian ada di antara kedua pundaknya seperti telur burung puyuh.” (Muttafaq Alaih)

Nabi saw pun memerintahkan untuk memberi makanan dan pakaian kepada anak sebagai jaminan kehidupan baginya. Ubadah bin $\mathrm{Al}$ Walid berkata, Rasulullah bersabda, "...Berilah mereka makan dari apa yang kalian makan dan berilah mereka pakaian dari apa yang kalian pakai...". ${ }^{16}$

5. Hak untuk mendapatkan perlindungan dalam kegiatan politik, pelibatan sengketa, peperangan, kerusuhan dan kekerasan.

Rasulullah saw melarang membunuh anak-anak ketika terjadi peperangan :

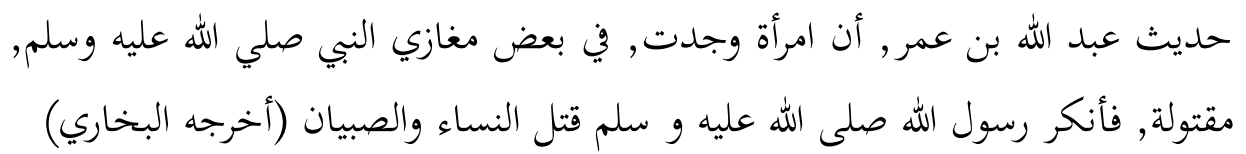
"Abdullah bin Umar r.a. berkata : Pernah terjadi dalam salah satu peperangan Nabi saw ada wanita terbunuh, maka Nabi saw murka dan melarang pembunuban terhadap wanita dan anak-anak". (Bukhari Muslim).

Tawanan perang dalam Islam bukanlah rakyat dari negeri yang berhasil dikalahkan, melainkan individu yang ikut bertempur. Rasulullah saw bersabda kepada penduduk Mekkah pada peristiwa Fathu Mekkah: "Pergilah Kalian, kalian adalah orang-orang yang telah bebas." Suku-suku Arab biasa membawa anak dan istri mereka dalam peperangan, sehingga selalu terdapat regu perempuan bagian logistik di belakang pasukan perang. Ketika pasukan utamanya kalah, maka perempuan serta anak-anak yang ikut berperang tertangkap, sehingga ikut menjadi tawanan perang. Tawanan perang termasuk ghanimah dan terbagi dalam dua bagian, yaitu wanita dan anak kecil, serta laki-laki yang sudah baligh. ${ }^{17}$

6. Hak mendapatkan hukuman yang sesuai dan manusiawi.

16Shahih, Adabul Mufrad, 566.

${ }^{17}$ Sayyid Sabiq. Fikib Sunab (Jakarta: Penerbit Pena), 2006, Jilid 4. 
Abdullah bin Busr Al Mazini berkata : "Ibuku mengutusku untuke mengantarkan setangkai anggur kepada Rasulullah. Namun, aku memakannya sebelum sampai kepada beliau. Ketika aku tiba di tempat beliau, beliau menjewer telingaku (secara halus) dan memanggilku dengan sebutan, "Wabai pengbianat kecil." 18

Rasulullah bersabda: "Apabila seseorang di antara kalian memukul, maka bindarilah bagian wajah."

\section{Perkara Hadhonah Di Pengadilan Agama Curup Kelas 1B Tahun 2016}

Di Pengadilan Agama Curup berdasarkan data yang diterima penulis, selama tahun 2016 perkara mengenai hak asuh anak atau badhanah hanya terdapat 1 perkara. Perkara tersebut Nomor 262/Pdt.G/2016/PA.Crp. Perkara ini merupakan perkara yang bersamaan dengan perkara cerai gugat.

Perkara Nomor 262/Pdt.G/2016/PA.Crp merupakan perkara diantara penggugat yang bertempat tinggal di Kabupaten Kepahiang yang dalam hal ini diwakilkan oleh kuasa hukum M. Guruh Indrawan, SH., MSi. Sedangkan penggugat bertempat tinggal di kabupaten Kepahiang, bekerja sebagai wiraswasta.

Gugatan perkara ini teregister pada tanggal 03 Mei 2016. Dalam gugatan perkara ini terdapat 11 point yang menjadi alasan mengapa perkara ini didaftarkan. Adapun point yang berkaitan dengan permasalahan badhanah yaitu point ke-sepuluh yang berbunyi:

"Bahwa oleh karena anak (keturunan) antara penggugat dengan tergugat yakni bernama ANAK terbilang masih kecil maka adalah tepat dan benar apabila penggugat ditetapkan sebagai wali ibu atas anak yang masih kecil tersebut. Hal ini sesuai dengan yurisprudensi Mahkamah Agung Republik Indonesia, yaitu putusan Mahkamah Agung RI No. 27/K/Pdt/1993 tanggal 30 Agustus 1993 yang antara lain menyebutkan bahwa anak-anak yang masih kecil berada di bawah asuhan ibunya." 20 berikut: ${ }^{21}$

Berdasarkan alasan diatas penggugat mengajukan tuntutan sebagai

1. Menetapkan Penggugat sebagai wali ibu atas anak bernama ANAK (11 Tahun) berjenis kelamin laki-laki lahir di Embong Sido tanggal 7 Agustus 2004.

\footnotetext{
${ }^{18}$ Musnad Asy Syamiyyin: II, 355.

${ }^{19}$ Muslim, Kitab Birri wash Shilah, No. 4729.

${ }^{20}$ Berkas perkara Nomor 262/Pdt.G/2016/PA.Crp., h. 5.

${ }^{21}$ Berkas perkara Nomor 262/Pdt.G/2016/PA.Crp ., h. 5-6.
} 
2. Menghukum Tergugat membayar biaya hidup, perawatan dan biaya sekolah anak bernama ANAK sebesar Rp 5.000.000 (lima juta rupiah) perbulan melalui penggugat sampai anak tersebut dewasa yang harus dibayarkan oleh tergugat pada setiap awal bulan.

Ketika persidangan pada saat agenda jawaban tergugat, point-point diatas ditanggapi tergugat dengan mengatakan bahwa tetap ingin anaknya berada dibawah pengasuhannya. Dan apabila penggugat pergi meninggalkan rumah, masalah pemeliharaan anak merupakan tanggung jawab tergugat selaku ayah anak. Tergugat juga menyampaikan bahwa mengenai masalah hak asuh anak, tergugat tidak pernah melarang anaknya untuk ikut dengan penggugat selaku ibunya. Namun anak itu sendiri yang tidak mau ikut dengan ibunya. Mengenai biaya nafkah anak yang diminta oleh penggugat, tergugat tidak dapat menyanggupinya dikarenakan penghasilan tergugat sebagai penjaga sekolah yang berstatus honorer hanya sebesar Rp 600.000,- perbulannya.

Pada sidang berikutnya dengan agenda replik penggugat menanggapi permasalahan jawaban tergugat mengenai tiada larangan untuk anak ikut ibunya. Penggugat mengajukan permohonan agar anak ikut penggugat dan dipindahkan kesekolah di dekat rumah penggugat. Namun tidak didizinkan oleh penggugat. Bahkan pada saat itu ibu penggugat mengatakan bahwa jika penggugat mau pergi, silakan pergi tapi jangan bawa anak, biarlah anak tinggal disini. ${ }^{22}$ Masih menurut penggugat, seharusnya tergugat tidak perlu membantah karena tergugat telah menyampaikan tidak ada masalah mengenai anak ikut penggugat atau tergugat. Apalagi tergugat juga sudah menyanggupi membiayai nafkah anak sesuai kemampuannya.

Dalam dupliknya tergugat menyampaikan apabila anak ikut tergugat maka secara keseluruhan biaya terhadap anak menjadi tanggungjwab tergugat. Tetapi apabila anak tersebut ikut penggugat maka tergugat hanya sekedar membantu sesuai dengan kemampuan tergugat. Karena tergugat berpenghasilan tidak sebanyak yang dituntut oleh penggugat.

Di agenda persidangan pembuktian, dihadirkan lah Anak penggugat dan tergugat untuk didengarkan kesaksiannya. Anak berumur 12 tahun, beragama Islam, peelajar di SDN 06 Bermani Ilir sekarang bertempat tinggal di Desa Embong Sido Kecamatan Bermani Ilir Kabupaten Kepahiang. Dalam kesaksiannya, Anak memberikan keterangan sebagai berikut:

1. Bahwa anak sekarang tinggal dengan tergugat.

${ }^{22}$ Berkas perkara Nomor 262/Pdt.G/2016/PA.Crp., h. 10. 
2. Bahwa anak memilih tinggal dengan tergugat karena penggugat sering meninggalkannya dan kepergian penggugat tersebut untuk mencari nafkah membantu keuangan keluarga.

3. Bahwa anak menyatakan bahwa ibunya (Penggugat) dengan ayahnya (Tergugat) tidak tinggal serumah lagi semenjak lima bulan yang lalu dan semenjak itu dia tinggal bersama tergugat di Desa Embong Sido sedangkan Penggugat sebagai ibunya tinggal di Desa Pasemah.

4. Bahwa anak pernah mengunjungi ibunya (Penggugat) di Desa Pasemah dan juga Penggugat pernah datang ke Desa Embong Sido untuk mengambil barang seperti kuali dan periuk dan Penggugat pernah memberi uang jajan kepada Anak

5. Bahwa Anak merasa nyaman dan senang tinggal bersama ayahnya (Tergugat) karena di Desa Embong Sido ada kakek dan nenek juga dia banyak mempunyai teman baik di rumah maupun sekolah.

6. Bahwa Anak menyatakan sudah bersungguh-sungguh tinggal bersama dengan tergugat.

7. Bahwa Anak menyatakan penggugat sebagai ibunya membolehkan menjenguk anaknya Anak dan begitu juga sebaliknya Anak tidak keberatan bila di ajak oleh penggugat pergi ke rumah neneknya di Desa Pasemah bila libur sekolah.

Berdasarkan keterangan-keterangan diatas majelis hakim memberikan keputusan hak hadhanah berada di bawah hadhanah tergugat. Dengan berbagai pertimbangan yaitu:

Karena anak penggugat dan tergugat yang bernama Anak lahir pada tanggal 7 Agustus 2004 yang sampai sekarang sudah berumur lebih dari 12 tahun, sesuai dengan Pasal 105 huruf b pemeliharaan anak yang sudah mummayiz diserahkan kepada anak untuk memilih diantara ayah dan ibunya sebagai pemegang hak pemeliharaannya. Untuk itu majelis hakim telah mendengarkan keterangan anak Penggugat dan Tergugat di persidangan serta dikuatkan dengan keterangan anak penggugat dan tergugat di persidangan. Kemudian ditambah lagi dengan keterangan saksi-saksi yang hadir yang intinya menerangkan bahwa Anak memilih untuk tinggal bersama Tergugat alias ayahnya. Karena penggugat sebagai ibu kandungnya lebih sering meninggalkan anak guna mencari nafkah untuk membantu ekonomi keluarga. ${ }^{23}$

Disamping itu Anak menyatakan merasa nyaman dan senang tinggal bersama dengan tergugat di Desa Embong Sido tempat tinggal Tergugat karena ada kakek dan nenek serta banyak teman-temannya baik dirumah maupun disekolah. Dengan kata lain Anak lebih memilih untuk tinggal bersama Tergugat,

23Berkas perkara Nomor 262/Pdt.G/2016/PA.Crp., h. 23. 
karena sudah terbukti selama ini Anak telah hidup tenang dan tentram bersama tergugat. Demi kemaslahatan dan kepentingan serta tumbuh kembangnya anak, maka hak pemeliharaannya ditetapkan kepada Tergugat. Maka dari itu majelis hakim menolak petitum Penggugat tentang hak asuh anak. ${ }^{24}$

Namun majelis hakim tetap menegaskan dalam putusannya tentang tergugat tidak dibenarkan menghalangi penggugat sebagai ibu kandungnya untuk bertemu dengan anak. Karena bagaimanapun seorang anak tetap membutuhkan kasih sayang kedua orangtuanya. Hal ini ditegaskan majelis hakim kasasi dalam pertimbangannya pada putusan Mahkamah Agung Nomor $110 \mathrm{~K} / \mathrm{AG} / 2007$ tanggal 13 November 2007 dengan mengemukakan:

"Bahwa sekalipun anak yang bernama..... ditetapkan di bawah badhanah pemohon kasasi/tergugat selaku ayahnya, akan tetapi tidak boleh memutuskan hubungan komunikasi dengan termohon kasasi/penggugat selaku ibunya dan termohon kasasi/penggugat selaku ibunya, dan termohon kasasi/penggugat mempunyai hak untuk berkunjung atau menjenguk dan membantu mendidik serta mencurahkan kasih sayangnya sebagai seorang ibu terhadap anaknya."

Petitum mengenai biaya pemeliharaan anak yang diajukan penggugat kepada tergugat sebesar Rp 5.000.000,- perbulan yang dibayarkan tiap awal bulan sampai anak dewasa, dinyatakan ditolak oleh majelis hakim. Hal tersebut dikarenakan hak asuh anak sudah berada di bawah hak tergugat. Maka semua biaya pemeliharaan ditanggung oleh tergugat sesuai dengan pasal 105 huruf $\mathrm{c}$ Kompilasi Hukum Islam yang menyatakan bahwa biaya pemeliharaan ditanggung bapaknya.

\section{Pelaksanaan Eksekusi Putusan Perkara Hadhonah Di Pengadilan Agama Curup Kelas 1b Tahun 2016}

Sejauh ini mengenai pelaksanaan eksekusi putusan perkara hadhanah di Pengadilan Agama Curup pada tahun 2016 belum pernah dilaksanakan. Karena menurut hakim Pengadilan Agama Curup M. Aliyuddin, S.Ag, MH., dan paniteraPengadilan Agama Curup Dra. Leni Puspawati belum ada kepastian di dalam aspek perekonomian di pihak-pihak yang berpekara. Dengan kata lainnya belum ada kepastian tentang berapa penghasilan di pihak mantan suami yang memang berdasarkan ketentuan hukum Islam maupun peraturan perundangundangan dibebankan untuk bertanggung jawab dalam hal menafkahi anak.

Faktor-faktor yang mempengaruhi belum pernah dilaksanakan eksekusi hadhanahdi Pengadilan Agama Curup adalah: ${ }^{25}$

${ }^{24}$ Berkas perkara Nomor 262/Pdt.G/2016/PA.Crp., h. 24.

25 Wawancara Dengan Hakim Pengadilan Agama Curup Kelas Ib, Aliyuddin dan Panitera Leni Puspawati Pada Tanggal 04 Oktober 2017. 
1. Pemahaman masyarakat yang masih kurang mengenai permohonan eksekusi atas penguasaan anak, sehingga sering terjadi masyarakat atau pencari keadilan cukup menyelesaikan secara kekeluargaan.

2. Prosedur eksekusi yang memakan waktu lama

3. Istri atau Suami yang mengajukan cerai, hanya ingin bebas dari suami atau istri, sehingga masalah siapa yang berhak atas anak tidak terjadi persoalan pokok dan mendasar.

4. Kendala struktural, kultural, sosiologis dan psikologis masyarakat yang masih bersifat kolektif yang mengedepankan asas kekeluargaan.

Pada dasarnya eksekusi putusan perkara hadhanah tersebut merupakan wewenang Pengadilan Agama, namun yang menjadi pertimbangan utama majelis hakim adalah kondisi anak. ${ }^{26}$ Misalnya dalam perkara Nomor 262/Pdt.G/2016/PA.Crp. diatas, hak hadhanah jatuh kepada Bapak padahal dijelaskan dalam Kompilasi Hukum Islam bahwa: ${ }^{27}$

\section{Pasal 105}

4) Pemeliharaan anak yang belum mumayyiz atau belum berumur 12 tahun maka hak ibunya.

5) Pemeliharaan anak yang sudah mumayyiz diserahkan kepada anaknya untuk memilih diantara bapaknya.

6) Biaya pemeliharaan ditanggung bapaknya.

\section{Pasal 106}

3) Orang tuanya berkewajiban merawat dan mengembangkan harta anaknya yang belum dewasa atau dibawah pengampuan dan tidak diperbolahkan memindahkan kecuali karena keperluan mendesak.

4) Orang tua bertanggung jawab atas kerugian atas yang ditimbulkan karena kesalahan dan kelalaian dari dari kewajiban tersebut pada ayat (1)

Namun karena pada saat itu kondisi anak lebih nyaman dan tentram bersama dengan Bapaknya karena Ibunya sering pergi meninggalkan anak untuk memenuhi kebutuhan rumah tangga, maka majelis hakim lebih mendengarkan keinginan anak. Apalagi Anak sudah dalam kategori mummayiz. Dengan kata lain aturan KHI mengenai hak asuh yang lebih dominan ke ibu bersifat tidak mutlak. Walaupun dalam perkara ini alasan Ibunya sering meninggalkan Anak karena mencari nafkah yang tidak tercukupi oleh bapaknya. Dinilai oleh majelis hakim

${ }^{26}$ Wawancara Dengan Hakim Pengadilan Agama Curup Kelas Ib, Aliyuddin Pada Tanggal 04 Oktober 2017.

27 Tim Redaksi Pustaka Yustisia, Hukum Keluarga: Kumpulan Perundangan tentang Kependudukan, Kompilasi Hukum Islam, Perkawinan, Perceraian, KDRT da Anak, (Jakarta; Pustaka Yustisia, 2010), Cetakan Pertama., h.284. 
sebagai permasalahan antara ibu dan bapak anak tersebut dan tidak berkaitan dengan pertimbangan tentang penetapan hak hadhanah.

Terlebih lagi dalam persidangan Anak memberikan kesaksian bahwa ingin tetap bersama ayahnya. Walaupun dalam hukum perdata anak-anak yang dibawah usia 15 tahun dianggap tidak cakap dalam memberikan kesaksian, tetapi apabila mereka memberi keterangan di persidangan, keterangan tersebut dinilai sebagi penjelasan bukan sebagai alat bukti. ${ }^{28}$

Kalaupun pada misalnya ada perkara yang hak hadhanahnya jatuh ke tangan ibu namun perawatan anak belum berada ditangan ibu alias di bapaknya, diajukan permohonan eksekusi. Pada saat eksekusi si anak menangis tidak mau ikut dengan ibunya, maka eksekusi tersebut tidak bisa dilaksanakan. Hal tersebut dikarenakan alasan yang diawal tadi yaitu bergantung pada kondisi anak, baik anak itu belum mummayiz maupun sudah mummayiz.

Pembahasan hak dan kewajiban anak dalam Undang-undang Perlindungan Anak Nomor 23 tahun 2002 terdapat pada Bab III, dari pasal 4 sampai pasal 19. Hak anak dalam UU tersebut meliputi: ${ }^{29}$

1. Setiap anak berhak untuk dapat hidup, tumbuh, berkembang, dan berpartisipasi secara wajar sesuai dengan harkat dan martabat kemanusiaan, serta mendapat perlindungan dari kekerasan dan diskriminasi (Pasal 4).

2. Setiap anak berhak atas suatu nama sebagai identitas diri dan status kewarganegaraan (Pasal 5).

3. Setiap anak berhak untuk beribadah menurut agamanya, berpikir, dan berekspresi sesuai dengan tingkat kecerdasan dan usianya, dalam bimbingan orang tua (Pasal 6). Setiap anak berhak untuk mengetahui orang tuanya, dibesarkan, dan diasuh oleh orang tuanya sendiri.

4. Dalam hal karena suatu sebab orang tuanya tidak dapat menjamin tumbuh kembang anak, atau anak dalam keadaan terlantar maka anak tersebut berhak diasuh atau diangkat sebagai anak asuh atau anak angkat oleh orang lain sesuai dengan ketentuan peraturan perundang-undangan yang berlaku (Pasal 7).

5. Setiap anak berhak memperoleh pelayanan kesehatan dan jaminan sosial sesuai dengan kebutuhan fisik, mental, spiritual, dan sosial (Pasal 8).Setiap anak berhak memperoleh pendidikan dan pengajaran dalam rangka pengembangan pribadinya dan tingkat kecerdasannya sesuai dengan minat dan bakatnya.

6. Selain hak anak sebagaimana dimaksud dalam ayat (1), khusus bagi anak yang menyandang cacat juga berhak memperoleh pendidikan luar biasa, 12)., h. 623.

${ }^{28}$ M. Yahya Harahap, Hukum Acara Perdata,(Jakarta: Sinar Grafika, 2012, Cetakan ke ${ }^{29}$ UU RI No. 23 tahun 2002 tentang Perlindungan Anak, Kementerian Pemberdayaan Perempuan RI dan Departemen Sosial, h. 16-20. 
sedangkan bagi anak yang memiliki keunggulan juga berhak mendapatkan pendidikan khusus (Pasal 9).

7. Setiap anak berhak menyatakan dan didengar pendapatnya, menerima, mencari, dan memberikan informasi sesuai dengan tingkat kecerdasan dan usianya demi pengembangan dirinya sesuai dengan nilai-nilai kesusilaan dan kepatutan (Pasal 10).

8. Setiap anak berhak untuk beristirahat dan memanfaatkan waktu luang, bergaul dengan anak yang sebaya, bermain, berekreasi, dan berkreasi sesuai dengan minat, bakat, dan tingkat kecerdasannya demi pengembangan diri (Pasal 11).

9. Setiap anak yang menyandang cacat berhak memperoleh rehabilitasi, bantuan sosial, dan pemeliharaan taraf kesejahteraan sosial (Pasal 12).

10. Setiap anak selama dalam pengasuhan orang tua, wali, atau pihak lain mana pun yang bertanggung jawab atas pengasuhan, berhak mendapat perlindungan dari perlakuan:
a. Diskriminasi;
b. Eksploitasi, baik ekonomi maupun seksual;
c. Penelantaran;
d. Kekejaman, kekerasan, dan penganiayaan;
e. Ketidakadilan; dan
f. Perlakuan salah lainnya (Pasal 13).

11. Dalam hal orang tua, wali atau pengasuh anak melakukan segala bentuk perlakuan sebagaimana dimaksud dalam ayat (1), maka pelaku dikenakan pemberatan hukuman (Pasal 13).

12. Setiap anak berhak untuk diasuh oleh orang tuanya sendiri, kecuali jika ada alasan dan/atau aturan hukum yang sah menunjukkan bahwa pemisahan itu adalah demi kepentingan terbaik bagi anak dan merupakan pertimbangan terakhir (Pasal 14).

Eksekusi hak hadhanah anak tidak semudah eksekusi perkara lain. Dalam eksekusi perkara hadhanah yang menjadi objek eksekusi adalah anak-anak atau dengan kata lain manusia bukan benda. Jika objek eksekusi itu dalam bentuk benda baik itu benda bergerak maupun tidak bergerak maka akan sangat mudah untuk memindahkannya.

Di Pengadilan Agama Curup, kebanyakan perkara hadhanah tidak diajukan dalam petitum para orangtua yang bercerai. Mereka lebih sering menyelesaikan permasalahan hadhanah dengan cara damai, apalagi mengenai biaya pemeliharaan anak. Ada juga yang memilih untuk menyelesaikan permasalahan hadhanah dengan perjanjian biaya pemeliharaan anak diambil dari 
harta gono-gini atau harta bersama selama mereka menikah. ${ }^{30}$ Dengan melakukan perjanjian dalam akta damai yang mereka lakukan pada saat tahap mediasi, bahkan terkadang jauh sebelum pasangan tersebut mengajukan permohonan maupun gugatan cerai.

Selain alasan dari pihak-pihak yang berpekara, ada juga alasan tambahan mengapa eksekusi hadhanah belum pernah terjadi di Pengadilan Curup yaitu biaya eksekusi. Biaya eksekusi yang ada di Pengadilan Agama Curup berdasarkan radius dimana alamat pihak berpekara sama halnya dengan biaya cerai gugat ataupun cerai talak biasa menggunakan radius. Namun biaya permohonan ekseskusi lebih mahal dari permohonan perkara biasa. Berikut tabel biaya berpekara di Pengadilan Agama Curup: ${ }^{31}$

Tabel biaya berpekara di Pengadilan Agama Curup

\begin{tabular}{|l|l|r|r|r|r|c|}
\hline \multirow{2}{*}{ No } & \multirow{2}{*}{ Uraian } & \multicolumn{5}{|c|}{ Radius } \\
\cline { 3 - 7 } & & \multicolumn{1}{|c|}{ I } & \multicolumn{1}{c|}{ II } & III & IV & V \\
\hline 1 & Tingkat I & & & & & \\
\hline & a.Cerai gugat & 391.000 & 631.000 & 841.000 & 1.051 .000 & 1.291 .000 \\
\cline { 2 - 7 } & b.Cerai Talak & 491.000 & 811.000 & 1.091 .000 & 1.371 .000 & 1.691 .000 \\
\hline 2 & Banding & 650.000 & 930.000 & 1.175 .000 & 1.420 .000 & 1.700 .000 \\
\hline 3 & Kasasi & 850.000 & 1.050 .000 & 1.225 .000 & 1.400 .000 & 1.600 .000 \\
\hline 4 & $\begin{array}{l}\text { Peninjauan } \\
\text { Kembali }\end{array}$ & 2.800 .000 & 2.960 .000 & 3.100 .000 & 3.240 .000 & 3.400 .000 \\
\hline 5 & Sita & 1.056 .000 & 1.426 .000 & 1.756 .000 & 2.336 .000 & 2.956 .000 \\
\hline 6 & Pemeriksaan & 900.000 & 1.190 .000 & 1.450 .000 & 1.690 .000 & 2.400 .000 \\
\hline 7 & Sita Eksekusi & 850.000 & 1.100 .000 & 1.325 .000 & 1.800 .000 & 2.200 .000 \\
\hline 8 & Eksekusi & 1.006 .000 & 1.376 .000 & 1.960 .000 & 2.606 .000 & 3.006 .000 \\
\hline
\end{tabular}

Biaya eksekusi ini memang cukup besar jika dibandingkan dengan biaya perkara lain bahkan melebihi besarnya biaya pemeriksaan pokok perkara. Hal ini disebabkan objek-objek sengketa letaknya terpencar di daerah-daerah yang letaknya sangat jauh dari pengadilan. ${ }^{32}$ Sampai saat ini dapat atau tidaknya suatu eksekusi atas suatu putusan perkara dilakukan sangat tergantung mampu tidaknya pemohon eksekusi membayar biaya untuk eksekusi. Pengadilan tidak akan bisa berbuat apa-apa apabila pihak yang dihukum tidak mau melaksanakan putusan.

30 Wawancara Dengan Hakim Pengadilan Agama Curup Kelas Ib, Aliyuddin Pada Tanggal 04 Oktober 2017.

${ }^{31}$ Data dari Pengadilan Agama Curup kelas Ib.

${ }^{32} \mathrm{http}: / /$ pa-surolangun.do.id/index.php/122-berita2014/464-artikel-waka-3,diakses tanggal 13 Oktober 2017 


\section{Konsistensi Tingkat Pelaksanaan Putusan Perkara Hadhonah Di Pengadilan Agama Curup Kelas 1b Tahun 2016}

Pada dasarnya ada dua bentuk eksekusi ditinjau dari segi sasaran yang hendak dicapai oleh hubungan hukum yang tercantum dalam putusan. Adakalanya sasaran hubungan hukum yang hendak dipenuhi sesuai dengan amar atau dictum putusan yaitu melakukan suatu perbuatan tindakan nyata atau tindakan rill. Sehingga eksekusi semacam perkara hadhanah ini disebut dengan eksekusi rill. ${ }^{33}$

Mengenai pelaksanaan eksekusi putusan perkara hadhanah di Pengadilan Agama Curup pada tahun 2016 belum pernah dilaksanakan. Maka terjawab sudah bahwa konsistensi tingkat pelaksanaan putusan perkara Hadhanah di Pengadilan Agama Curup kelas Ib tahun 2016 tidak dapat terlihat dan tidak dapat ditentukan. Karena pada tahun 2016 perkara hadhanah hanya terdapat satu perkara saja. Dan lagipula perkara tersebut tidak sampai ke tahap eksekusi. Terbukti dengan tidak dilakukannya perlawanan banding dan permhonan eksekusi oleh pihak termohon maupun pemohon atas putusan tersebut. Tambahan alasannya berdasarkan keterangan tergugat di dalam agenda persidangan bahwa memang si Anak sudah tinggal dengan tergugat sebelum putusan itu keluar, yang dibenarkan oleh penggugat dan para saksi. ${ }^{34}$

Selain itu secara teori hukum acara perdata eksekusi berkaitan dengan prinsip kondemnator. Ciri putusan yang bersifat kodemnator adalah putusan yang terdapat dalam amarnya pernyataan penghukuman terhadap tergugat untuk melakukan suatu perbuatan. ${ }^{35}$

Setiap putusan kodemnatoir dengan sendirinya memiliki kekuatan eksekutorial. ${ }^{36}$ Dan dalam perkara hadhanah terlebih lagi dalam perkara Nomor 262/Pdt.G/2016/PA.Crp tidak terdapat ciri dari eksekusi yang bersifat kodemnatoir sehingga putusan tersebut tidak memiliki kekuatan esekutorial.

Masalah eksekusi atas anak, masih diperselisihkan oleh para pakar hukum dan praktisi hukum. Pendapat yang muncul dapat diklasifikasi dalam dua kelompok, yaitu Pendapat Pertama yang membolehkan, dengan alasan bahwa dalam HIR atau hukumnya dapat ditemukan antara lain dalam Pasal 259 ayat (1) R. Bg dan Pasal 319hBW. Eksekusi atas penguasaan anak dibenarkan demi kepentingan anak tersebut.

${ }^{33}$ Berdasarkan pasal 225 HIR pasal 259 RBG

${ }^{34}$ Berkas perkara Nomor 262/Pdt.G/2016/PA.Crp., h. 23.

${ }_{35}$ M. Yahya Harahap, Ruang Lingkup Permasalahan Eksekusi Bidang Perdata. (Jakarta: Sinar Grafika, 2017)., h. 23.

${ }^{36}$ Dapat dilakukan secara paksa oleh kekuatan umum. Baca M. Yahya Harahap, Loc.cit., h. 23. 
Termasuk alasan kelompok pertama bahwa perkembangan hukum yang dianut akhir-akhir ini menetapkan bahwa penguasaan anak yang putusnya bersifat condemnatoir, jika sudah berkekuatan hukum tetap, maka putusan tersebut dapat dieksekusi. Pengadilan mempunyai hak upaya paksa dalam melaksanakan putusan tersebut (execution force).

Pada tanggal 6 Juli 1999, Mahkamah Agung RI yang tergabung dalam TIM E menetapkan bahwa penguasaan anak dalam pelaksanaan eksekusinya merupakan upaya paksa dan dapat dijalankan, dan apabila ada yang menghalangi terhadap eksekusi itu dapat Dipidana sesuai dengan Pasal 216 (1) KUHP.

Pasal 319 KUH Perdata yang mengatakan bahwa jika pihak yang senyatanya menguasai anak-anak yang belum dewasa itu menolak, menyerabkan anak-anak itu, maka para pibak yang menurut keputusan pengadilan harus menguasai anak tersebut, boleh meminta melalui perantaran juru sita dan menyurub kepadanya melaksanakan keputusan $i^{i t u}{ }^{37}$

Dua kata kunci yang harus dipahami dalam Pasal 319 tersebut, pihak yang senyatanya menguasai anak-anak dan pihak yang menurut keputusan harus menguasai mereka. Kalimat pertama ditujukan kepada pihak yang dihukum untuk menyerahkan penguasaan anak atau orang lain yang diberi amanah. Kalimat kedua menunjukkan ada pihak-pihak yang harus menguasai anak secara hukum, sehingga dibenarkan untuk melakukan upaya hukum, termasuk mengajukan eksekusi atas anaknya.

Pendapat kedua mengatakan bahwa eksekusi atas anak tidak dibenarkan, dengan alasan bahwa anak itu tidak boleh dipaksa-paksa dan bersifat tidak manusiawi dan akan membahayakan mental anak (Pasal 33 HIR). Yurisprudensi yang terkait dengan eksekusi hanya dalam kaitannya dengan hukum benda, bukan orang. Putusan declatoir lazimnya hanya memberikan penetapan hak, tidak dapat dieksekusi melalui upaya paksa (execution Force). ${ }^{38}$ Dalam filosofi hukum pun dikenal, bahwa anak bukanlah benda yang dapat dibagi (in natura), oleh karena itu jalur dan lajur sukarela antara para pihak harus dilakukan demi kebaikan si anak.

Apapun alasan masing-masing pendapat diatas, sebenarnya pendapat pertama dapat dijadikan patokan hukum. Terhadap argument kelompok kedua, bahwa anak tidak manusiawi membiarkan anak-anak tersebut dibawah pengawasan orang tidak bertanggung jawab, tidak mampu secara hukum dan

${ }^{37}$ R. Subekti dan R Tjitrosudibio, Ktab Undang-Undang Hukum Perdata, (Jakarta: Pradnya Paramita, 2004), h. 88.

${ }^{38}$ H.A. Mukti Arto, Praktek Perkara Perdata Pada Pengadilan Agama, Pustaka Pelajar, Yogyakarta, 2003, hlm. 8. 
tidak sah secara hukum, boleh jadi upaya paksa melalui eksekusi akan lebih bermanfaat dari pada membiarkan dalam kemudaratan. ${ }^{39}$

Prosedur hukum acara eksekusipun, akan melalui tahap teguran (aanmanning), termasuk pemberitahuan atas adanya eksekusi. Langkah ini sudah cukup adil dan bijaksana dalam memberikan kesempatan kepada pihak-pihak yang tidak melaksanakan putusan secara sukarela. Upaya ini merupakan langkah psikologis yuridis, dengan memberikan dan kesempatan agar para pihak menyadari hak dan kewajibannya.

Ada juga yang mengatakan perlunya dwangsom dalam perkara hadhanah. Dwangsom atau astreinte adalah hukuman tambahan dalam putusan hakim terhadap orang yang dihukum untuk membayar sejumlah uang selain yang telah disebutkan dalam hukum mestinya dan tepat waktu. ${ }^{40}$ Lembaga dwangsom diatur dalam pasal 606 a dan 606 b B.Rv. yang mulai dipergunakan oleh Raad $V$ an Justitie dan Hoegerechtteshof tahun 1938, memang dalam HIR dan R. Bg, tidak disebutkan secara rinci.

Masih terjadi dualisme pemikiran dalam hal ini, ada yang berpendapat tidak layak diterapkan pada kasus hadhanah, dengan alasan konteksnya berbeda dengan ganti rugi (Pasal 225 HIR) atau kompensasi dalam hukum perdata atau masalah hutang piutang. Bagi kalangan yang berpendapat perlu dilakukan lembaga dwangsom dalam putusan hadhanah, dengan alasan: ${ }^{41}$

1. Sebagai langkah strategis dalam upaya mencegah para pihak tidak melaksanakan putusan dan mencegah keputusan hampa (ilusoir)

2. Hanya merupakan hukuman tambahan, bila hukuman pokok tidak dipenuhi, sehingga pelanggaran dwangsom pun dapat dieksekusi.

3. Sebagai tekanan psikis, sehingga dengan sukarela melaksanakan putusan

Pasal 225 HIR, Pasal 259 R.Bg., yaitu gugatan untuk melaksanakan suatu persetujuan berdasarkan pasal $1267 \mathrm{KUH}$ Perdata dapat dijadikan dasar dalam putusan yang memuat tuntunan dwangsom. Oleh karena itu, penggugat yang menuntut hadhanah, dapat mengajukan tuntunan dwangsom (pasal 606 a B. Rv) dengan didasarkan pada posita yang jelas. Besarnya dwangsom tidak berkenaan dengan gugatan pembayaran sejumlah uang. Tuntunan dwangsom dicantumkan secara jelas dan tegas dalam petitum. Majelis hakim yang memeriksa tuntunan hadhanah yang mencantumkan dwangsom harus benar-benar memperhatikan layak tidaknya untuk diterima dengan melihat kondisi ekonomis yang akan melaksanakan dwangsom. Termasuk layak tidaklah dwangsom dalam perkara yang sedang diperiksa dalam arti beralasan hukum atau tidak tuntutan dwangsom tersebut.

39 Abdul Manan, Penerapan Hukum Acara Perdata di Lingkungan Pengadilan Agama, (Jakarta: Kencana, 2005)., h. 438.

${ }^{40}$ Ibid.,h.439.

${ }^{41}$ Ibid., h. 440. 
Oleh sebab itu, diantara petitum yang terkait dengan tuntutan dwangsom atas hadhanah adalah: ${ }^{42}$

1 .

2 .

$3 \ldots \ldots \ldots \ldots$

4. Menghukum tergugat untuk membayar kepada penggugat sebesar Rp...............) setiap hari keterlambatan melaksanakan putusan ini terhitung sejak putusan ini berkekuatan hukum tetap.

Dalam amar putusan bila tuntutan dwangsom diterima maka berbunyi : menghukum tergugat untuk membayar uang paksa sebesar Rp................) setiap hari, setiap penggugat melalaikan putusan berkekuatan hukum tetap.

\section{Penutup}

Jumlah perkara hadhonah di Pengadilan Agama Curup kelas 1B tahun 2016 adalah satu perkara yaitu perkara Nomor 262/Pdt.G/2016/PA.Crp. Perkara ini merupakan perkara yang bersamaan dengan perkara cerai gugat.Pelaksanaan eksekusi putusan perkara hadhonah di Pengadilan Agama Curup kelas 1B tahun 2016 belum pernah dilakukan dikarenakan pemahaman masyarakat mengenai eksekusi masih kurang, biaya eksekusi yang tergolong mahal dan masih kuatnya asas kekeluargaan dalam masyarakat dalam menyelesaikan masalah.

Konsistensi tingkat pelaksanaan putusan perkara hadhonah di Pengadilan Agama Curup kelas 1B tahun 2016 tidak dapat terlihat dan tidak dapat ditemukan. Hal tersebut disebabkan belum pernah ada pihak-pihak berpekara yang mengajukan banding maupun permohonan kasasi terhadap putusan hadhanah.

Hendaknya institusi berkaitan lebih memberikan sosialisasi atau pengetahuan terhadap masyarakat mengenai permasalahan eksekusi hak asuh anak atau hadhanah. Agar dapat menghindari dampak buruk ke anak yang berada dalam keluarga pasca bercerai. Sehingga apabila ada permohonan mengenai eksekusi hadhanah dapat dilaksanakan dengan baik.Perlunya ditinjau kembali mengenai biaya eksekusi. Karena setiap objek eksekusi berbeda jenisnya, terlebih lagi eksekusi hadhanah yang sifatnya objeknya bukan benda.Dan juga perlunya pembinaan pemahaman hukum di dalam masyarakat supaya tingkat kesadaran hukum masyarakat bukan hanya untuk tertib keperdataan saja. 


\section{Daftar Pustaka}

A. Rasyid, Roihan, Hukum Acara Peradilan Agama, Cet ke-14, Jakarta: Rajawali Pers, 2010.

Abu, Muhammad Bakar, Terjemah Subulussalam juz III, Surabaya: Al-Ikhlas, 1955.

Allamah, Syaikh Muhammad bin Abdurrahman ad-Dimasyqi, Fikib Empat Mą̧bab, terj. Abdullah Zaki Alkaf, (Bandung: Hasyimi, 2010), Cet. ke-13.

Arto, H.A. Mukti, Praktek Perkara Perdata Pada Pengadilan Agama, Pustaka Pelajar, Yogyakarta, 2003.

Aziz, Abdul dan Abdul Wahhab, Fiqh Munakahat, terj. Abdul Majid, Jakarta: Amzah, 2011, Cetakan Ke-2.

Aziz, Abdul Dahlan, Ensiklopedia Hukum Islam, Jakarta: Ikhtiar Baru Van Hove, 1999.

Bintania, Aris, Hukum Acara Peradilan Agama dalam Kerangka Figh al-Qadha, cetakan pertama, Jakarta: Rajawali Pers. 2012.

Djafar, Muhammadiyah. Pedoman Ibadah Muslim dalam Empat Madz̧ab Sunni dan dalil-dalilnya, Jawa Timur : GBI (Anggota IKAPI), 1993, Cet-1.

Departemen Agama, Al-Quran dan Terjemahnya.Bandung: Diponegoro. 2006.

Gempur, Santoso, Metodologi Penelitian, Jakarta: Prestasi Pustaka Publisher, 2012, Cetakan ke tiga.

Hafizh, ibn Hajar Asqalani, Bulugbul Maram, terj. Moh. Machfuddin Aladip, Semarang: Toha Putra, 2010.

Hakim, Rahmat, Hukum Perkawinan Islam,Bandung, Pustaka Setia, 2000.

Harahap, M. Yahya, Hukum Acara Perdata,Jakarta: Sinar Grafika, 2012, Cetakan ke -12 .

Harahap, M. Yahya, Ruang Lingkup Permasalahan Eksekusi Bidang Perdata.Jakarta: Sinar Grafika, 2017.

H. A. Al-Hamdani, Risalah Nikah, Jakarta: Pustaka Amini, 2002.

Jawad, Muhammad Mughniyah, Fiqih 5 Maŗab, Jakarta: Lentera, 2002.

Kamal, Musthafa Pasha, Chalil, Wahardjani, Fiqih Islam, Jogyakarta: Citra Karsa Mandiri, 2002.

Lubis, Sulaikin, et all, Hukum Acara Perdata Peradilan Agama di Indonesia, Jakarta:Kencana Prenada Media Group, 2008, Cet. ke-3. 
44 Al-Istinbath: Jurnal Hukum Islam, Vol. 3, No. 1, 2018

Mahmood, Tahir. Personal Law in Islamic Countries, Tripathi : New Delhi, 1987.

Manan, Abdul, Penerapan Hukum Acara Perdata di Lingkungan Pengadilan Agama,Jakarta: Kencana, 2005.

Qaradhawi, Yusuf, Fatwa-Fatwa Kontemporer, terj. As'ad Yasin, Jakarta: Gema Insani, 2009, Cet. ke-6.

Qasim, Ibnu, Tausyih Ala Ibnu Qasim,Surabaya: Al-Hidayah, T'T.

R. Subekti, dan R Tjitrosudibio, Kitab Undang-Undang Hukum Perdata,Jakarta: Pradnya Paramita, 2004

Rofiq, Ahmad. Hukum Islam di Indonesia, Jakarta: Rajawali Pers, 2003, Cet-6.

Syarifudin, Amir, Hukum Perkawinan Islam di Indonesia, Jakarta:Media Pesada, 2007.

Sudarto, Achmad dkk, Terjemah Shahih Bukhari Jilid VII, Semarang: CV. AsySyifa, 1993.

Sabiq, Sayyid. Fikih Sunah Jakarta: Penerbit Pena, 2006, Jilid 4.

Tihami, H. M. A. dan Sohari Sahrani, Fikih Munakahat, Jakarta: Rajawali Pers, 2010, Cet. ke-2.

Tim Redaksi Pustaka Yustisia, Hukum Keluarga: Kumpulan Perundangan tentang Kependudukan, Kompilasi Hukum Islam, Perkawinan, Perceraian, KDRT dan Anak, Jakarta; Pustaka Yustisia, 2010, Cetakan Pertama.

UU RI No. 23 tabun 2002 tentang Perlindungan Anak, Kementerian Pemberdayaan Perempuan RI dan Departemen Sosial.

http://pa-selayar.do.id/index.php/122-berita2014/464-artikel diakses pada 15 Oktober 2017

http://pa-surolangun.do.id/index.php/122-berita2014/464-artikel-waka3,diakses tanggal 13 Oktober 2017 